(C) 1984. The Genetical Society of Great Britain

\title{
THE INHERITANCE OF QUANTITATIVE FITNESS TRAITS IN GUPPIES, POECILIA RETICULATA (PISCES: POECILIIDAE). II. TESTS FOR INBREEDING EFFECTS
}

\author{
JAMES A. FARR* AND KARIN PETERS \\ Institut für Biologie, Gesellschaft für Strahlen- und Umweltforschung, D-8042 Neuherberg \\ bei München, Federal Republic of Germany
}

Reeived 14.vii.83

\begin{abstract}
SUMMARY
We tested for the effects of a single generation of full-sib inbreeding on quantitative sexual behaviour patterns whose contributions to the reproductive success of male guppies, Poecilia reticulata, are known. The parental stocks were derived recently from natural populations in Trinidad and from an introduced population in Haiti. Contrary to an earlier report in which behavioural levels were correlated with level of heterozygosity, no overall additive effects of breeding system were found. However, significant breeding $\times$ father interactions suggest that breeding system can have an effect, but that different genotypes respond in different manners. The data support earlier findings of $Y$-linkage of major sexual behaviour patterns in inbred strains of guppies. The magnitude of autosomal influences on male sexual behaviour was consistent over three independent data sets, but the mode of action of autosomal factors appears to be very complex.
\end{abstract}

\section{INTRODUCTION}

Most studies of inbreeding in animals have concentrated primarily on its effects on fecundity, offspring viability, and abnormal morphology (e.g., Falconer, 1960; Wright, 1977; Ralls et al., 1979; Packer, 1979). A few have dealt with inbreeding effects on various behavioural measures, including reduced sexual vigour in Drosophila (Maynard Smith, 1956; Fulker, 1966), guinea pigs (Jakway, 1959), and mice (McGill, 1970), and reduced abilities to regulate hive temperatures and to recruit workers to a food source in honeybees, Apis mellifera (Brückner, 1975, 1976, 1978). In the present study we examine the contrasting effects of inbreeding and outcrossing on quantitative sexual behaviour patterns that influence fitness in male guppies, Poecilia reticulata.

The rate at which male guppies court females is a primary determinant of male mating success; those males with the highest rate of courtship display have a greater chance of encountering a receptive female and are preferred by females (Farr, 1980a). The courtship display consists of a sigmoid arching of the body with the unpaired fins either closed or fully spread (Baerends et al., 1955). The low-intensity display with closed fins is believed to be a probe of a female's receptivity, while the more conspicuous open display with spread fins is more likely to elicit a female response allowing copulation (Farr, 1977, 1980b). Males can also increase their reproductive success through forced inseminations (Farr, 1980a); they merely orient behind a female, erect the gonopodium (the anal fin modified

* Present Address: Department of Biological Science, Florida State University, Tallahassee, Florida 32306, U.S.A. 
into an intromittent organ), and attempt forcefully to insert the gonopodial tip into the female's gonopore. Inseminations through the display-acceptance route are more likely to result in offspring production than are those through gonopodial thrusting, because females are more likely to respond to a male's display when they possess ripe ova (Kadow, 1954; Liley, 1966), and because fresh sperm are more viable than older stored sperm (Winge, 1937; Hildemann and Wagner, 1954).

The inheritance of rates of courtship display and gonopodial thrusting is primarily through genes linked to the $Y$-chromosome, but autosomal factors can also influence sexual activity (Farr, 1983). Rate of closed courtship displays and the total number of courtship displays per unit time appeared to be correlated with degree of autosomal heterozygosity. The $\mathrm{F}_{1}$ male progeny produced by crossing two inbred strains were sexually more active than the paternal strains, indicating heterosis, and backcrossing the $F_{1}$ males to the original parental strains caused a reduction in rate of courtship. The backcrosses of $F_{1}$ males to the isogenic parental strains resulted in an average 50 per cent loss in heterozygosity. The rates of open courtship displays and gonopodial thrusting were not correlated with level of heterozygosity.

One generation of full-sib mating reduces heterozygosity by 50 per cent (Crow and Kimura, 1970). If heterozygosity and sexual activity are correlated, a single generation of inbreeding could result in male progeny at a significant reproductive disadvantage relative to outbred individuals. In the present study, we test whether one generation of full-sib inbreeding is sufficient to reduce levels of male sexual behaviour relative to outcrossing.

\section{MATERIALS AND METHODS}

Two outbred stocks of guppies polymorphic for secondary sexual colouration formed the basis for this experiment. One consisted of descendants of one population introduced into Haiti, and the other stock consisted of descendants of several wild populations in Trinidad. These are not isogenic inbred strains, and both stocks had been maintained in our laboratory in large collective breeding aquaria for less than ten generations. Although initial sampling and subsequent genetic drift have certainly reduced somewhat the genetic variability within these stocks as compared to the original parent populations in Haiti and Trinidad, the persistence of the polymorphism in male colouration and the tendency for females to mate with rare males (Farr, 1977, 1980a) indicate that all variation was not lost.

We made reciprocal crosses of Haiti males $\times$ Trinidad females and Trinidad males $\times$ Haiti females to produce two $F_{1}$ stocks, designated HT and $\mathrm{TH}$, respectively. These two stocks thus have identical mean genetic backgrounds and incorporate the genetic variation of both the Trinidad and Haiti parental stocks. Each of eight randomly chosen HT and eight TH males was then crossed with two females to produce an inbred and an outbred line with a common father. The inbred line was produced by crossing the male with a full sister $(F=0 \cdot 25)$. The outbred line was produced by pairing males with unrelated females of the opposite $F_{1}$ type; HT males were crossed with TH females, and TH males with HT females. Because our original Trinidad and Haiti stocks are not isogenic, the offspring from 
our outcrossed matings are on average heterozygous at more loci than are those from full-sib inbreeding. This mating scheme differs from that of Farr (1983), in which backcrosses of $F_{1}$ males to females of either inbred parental strain resulted in a 50 per cent loss of heterozygosity.

All crosses were performed in 10 litre aquaria. Where one male was crossed with two females, the two females were held in adjacent tanks and the male was transferred weekly from one tank to the other. Each female was allowed to produce at least three broods, and the broods were reared in the aquaria in which they were born. Females were transferred to new aquaria after giving birth.

All tanks with gravid females were planted with Fontinalis sp. as a refugium for newborn young. Water temperature was $23^{\circ} \mathrm{C}$, and the laboratory was kept on a 12:12 light: dark cycle. Fish were fed TetraMin dried flake food, supplemented at least twice weekly with live Artemia nauplii and Tubifex worms.

Behavioural observations were made on fish in 37.5 litre aquaria. Because single males in the presence of females exhibit very low levels of sexual behaviour (Farr and Herrnkind, 1974; Farr, 1976), each observation aquarium contained two males (full sibs) to be assayed and two gravid females, the latter from a third unrelated stock aquarium. Males were allowed a minimum of $24 \mathrm{~h}$ after transfer to the observation aquaria before their behaviour was quantified. Each male was observed for $30 \mathrm{~min}$, six periods of $5 \mathrm{~min}$ each. The following data were recorded:

(a) The number of closed courtship displays made in $30 \mathrm{~min}$ (C);

(b) The number of open courtship displays made in $30 \mathrm{~min}(\mathrm{O})$;

(c) The number of gonopodial thrusts made in $30 \mathrm{~min}(\mathrm{~T})$.

We then calculated for each male:

(d) The total number of courtship displays, closed plus open, made in $30 \mathrm{~min}(\mathrm{CO})$;

(e) The proportion of the total number of displays that were of the open type $(\mathrm{O} / \mathrm{CO})$

(f) The ratio of the number of gonopodial thrusts to the total number of displays $(\mathrm{T} / \mathrm{CO})$.

The breeding scheme allowed the following design for variance analysis. Individual fathers were nested within paternal $F_{1}$ type (HT or $\left.\mathrm{TH}\right)$, and breeding treatment (inbred or outbred) was crossed with both paternal $F_{1}$ type and individual fathers. The design controls for potential $Y$-linkage of the various behavioural traits by using a common father for testing the effects of inbreeding.

The design was intended to be completely balanced, with six offspring observed from each cross. However, owing to low fecundity and adult female and juvenile mortality, and occasional complete sexual inactivity of test males, the number of males tested per cross ranged from four to six. Rate of gonopodial thrusting required a log transformation, and the proportion of the total courtship displays of the open type $(\mathrm{O} / \mathrm{CO})$ required an arc sine transformation. Because ratios have undesirable statistical properties, the ratio of gonopodial thrusts to total courtship displays $(\mathrm{T} / \mathrm{CO})$ was analysed as the difference between two logarithms (ln T-ln CO). Two treatment variables, paternal $F_{1}$ type and breeding treatment, were fixed factors, and one, the individual fathers, was a random factor (Hays, 1973: See table 1). 
TABLE 1

Denominators for calculating $F$ ratios for ANOVAs of different genetic effects on quantitative sexual behaviour patterns of male guppies, Poecilia reticulata

\begin{tabular}{|c|c|c|c|}
\hline $\begin{array}{l}\text { Source of } \\
\text { variation }\end{array}$ & df & $\begin{array}{l}\text { Denominator for } \\
\text { F ratio }\end{array}$ & df for $F$ ratio \\
\hline Paternal $F_{1}$ type & 1 & Father $F_{l}$ type & 1,14 \\
\hline Father $1 F_{1}$ type & 14 & Residual & 14,146 \\
\hline Breeding & 1 & Breeding $\times$ father & 1,14 \\
\hline Breeding $\times$ father interaction & 14 & Residual & 14,146 \\
\hline $\begin{array}{l}\text { Breeding } \times \text { paternal type } \\
\text { interaction }\end{array}$ & 1 & Residual & 1,146 \\
\hline Maternal $F_{1}$ type & 1 & Maternal type $\times$ father & 1,14 \\
\hline $\begin{array}{l}\text { Maternal type } \times \text { paternal type } \\
\text { interaction }\end{array}$ & 1 & Residual & 1,146 \\
\hline Maternal type $\times$ father interaction & 14 & Residual & 14,146 \\
\hline Total treatments & 31 & Residual & 31,146 \\
\hline Residual & 146 & & \\
\hline Total & 177 & & \\
\hline
\end{tabular}

Care must be taken in the interpretation of the sums of squares in this analysis. The sum of squares for the interaction of paternal $F_{1}$ type $X$ breeding is also the sum of squares for effects of maternal $F_{1}$ type (a fixed factor), and the breeding sum of squares is also the sum of squares for the interaction of paternal $F_{1}$ type and maternal $F_{1}$ type (fig. 1). Because fathers are nested within paternal $F_{1}$ type, the interaction of individual fathers and breeding is identical to that for individual fathers $\times$ maternal $F_{1}$ type.

Finally we should point out that because the statistical design was not completely balanced, the sums of squares for individual treatments and interactions are not completely independent. We have used conservative estimates of all treatment effects and interactions, so the sum of all individual sums of squares is less than the total sum of squares in all analyses.

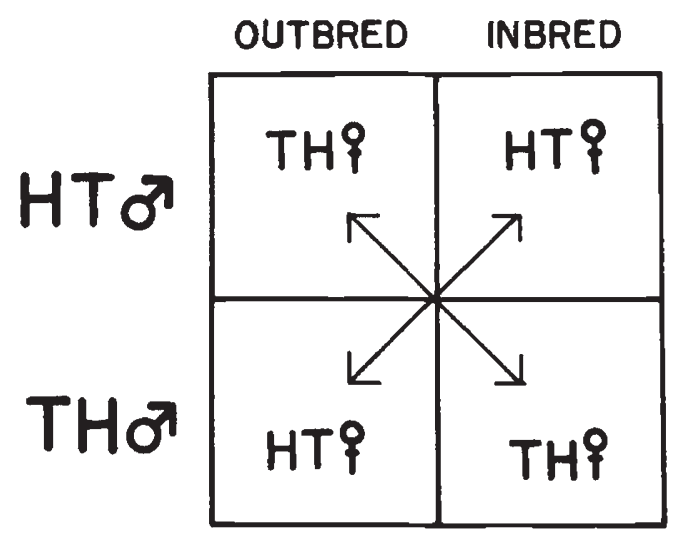

FIG. 1. A representation of the breeding scheme for tests of the effects of inbreeding. The interaction of breeding system $\times$ paternal $F_{1}$ type, indicated by the arrows, provides a test for the effects of maternal $F_{1}$ type. 


\section{RESULTS}

Although a prior study (Farr, 1983) indicated that at least two measures of male sexual behaviour, number of closed courtship displays and total number of courtship displays, were correlated with level of autosomal heterozygosity, no main effect of a single generation of full-sib inbreeding on any variable in this study could be detected (tables 2 and 3 ). There were no effects of paternal $F_{1}$ type (HT or $\mathrm{TH}$ ) on any variable. However, there

TABLE 2

Means and standard errors (in parentheses) for six quantitative measures of male sexual behaviour. The data are grouped by paternal $F_{1}$ type (HT or $\left.T H\right)$ and breeding treatment

\begin{tabular}{llrr}
\hline & Trait & HT father & \multicolumn{1}{c}{ TH father } \\
\hline Inbred & $\mathrm{C}$ & $11.87(0.96)$ & $10.23(1.08)$ \\
& $\mathrm{O}$ & $14.09(1.47)$ & $13.75(1.93)$ \\
& $\mathrm{CO}$ & $25.96(1.51)$ & $23.97(1.68)$ \\
& $\mathrm{T}$ & $3.09(0.68)$ & $3.53(0.82)$ \\
& O/CO & $0.49(0.04)$ & $0.48(0.05)$ \\
& $\mathrm{T} / \mathrm{CO}$ & $0.11(0.02)$ & $0.12(0.03)$ \\
Outbred & $\mathrm{C}$ & $9.69(0.84)$ & $10.79(0.88)$ \\
& $\mathrm{O}$ & $15.76(1.58)$ & $13.62(1.46)$ \\
& $\mathrm{CO}$ & $25.44(1.32)$ & $24.40(1.52)$ \\
& $\mathrm{T}$ & $3.62(0.71)$ & $2.53(0.54)$ \\
& $\mathrm{O} / \mathrm{CO}$ & $0.56(0.04)$ & $0.49(0.04)$ \\
& $\mathrm{T} / \mathrm{CO}$ & $0.13(0.02)$ & $0.09(0.02)$ \\
\hline
\end{tabular}

TABLES $3 a-f$

Analyses of variance for different influences on male sexual behaviour. The values between the solid lines use the same sums of squares and mean squares from the preceding three lines to recalculate $F$ ratios for tests of effects of maternal genotype on male behaviour. $C D=$ coefficient of determination

3a. Closed courtship displays $(C)$

\begin{tabular}{|c|c|c|c|c|c|c|}
\hline Source & df & $\begin{array}{l}\text { Sum of } \\
\text { squares }\end{array}$ & $\begin{array}{l}\text { Mean } \\
\text { square }\end{array}$ & F ratio & Significance & $\mathrm{CD}$ \\
\hline Paternal $F_{1}$ type & 1 & $3 \cdot 587$ & $3 \cdot 587$ & 0.033 & NS & \\
\hline Father $1 F_{1}$ type & 14 & 1522.036 & $108 \cdot 717$ & $4 \cdot 059$ & 0.005 & $22.0 \%$ \\
\hline Breeding & 1 & $35 \cdot 963$ & $35 \cdot 963$ & 0.715 & NS & \\
\hline $\begin{array}{l}\text { Breeding } \times \text { father } \\
\text { interaction }\end{array}$ & 14 & $704 \cdot 399$ & $50 \cdot 314$ & $1 \cdot 879$ & 0.05 & $10 \cdot 2 \%$ \\
\hline $\begin{array}{l}\text { Breeding } \times \text { paternal } \\
\text { type interaction }\end{array}$ & 1 & $127 \cdot 247$ & $127 \cdot 247$ & $4 \cdot 752$ & 0.05 & \\
\hline Maternal $F_{1}$ type & 1 & $127 \cdot 247$ & $127 \cdot 247$ & $2 \cdot 529$ & NS & \\
\hline $\begin{array}{l}\text { Maternal type } \times \\
\text { Paternal type } \\
\text { Interaction }\end{array}$ & 1 & $35 \cdot 963$ & $35 \cdot 963$ & $1 \cdot 343$ & NS & \\
\hline $\begin{array}{l}\text { Maternal type } \times \text { father } \\
\text { interaction }\end{array}$ & 14 & $704 \cdot 399$ & $50 \cdot 314$ & $1 \cdot 879$ & 0.05 & \\
\hline Total treatments & 31 & $3018 \cdot 075$ & $97 \cdot 357$ & $3 \cdot 636$ & 0.005 & $43 \cdot 6 \%$ \\
\hline Residual & 146 & $3909 \cdot 700$ & $26 \cdot 779$ & & & \\
\hline Total & 177 & $6927 \cdot 775$ & & & & \\
\hline
\end{tabular}


3b. Open courtship displays $(O)$

\begin{tabular}{|c|c|c|c|c|c|c|}
\hline Source & df & $\begin{array}{l}\text { Sum of } \\
\text { squares }\end{array}$ & $\begin{array}{l}\text { Mean } \\
\text { square }\end{array}$ & $\mathrm{F}$ ratio & Significance & $\mathrm{CD}$ \\
\hline Paternal $F_{1}$ type & 1 & $112 \cdot 528$ & $112 \cdot 528$ & 0.315 & NS & \\
\hline Father $1 F_{1}$ tyd & 14 & $5402 \cdot 365$ & $385 \cdot 883$ & $4 \cdot 439$ & 0.005 & $27 \cdot 1 \%$ \\
\hline Breeding & 1 & $33 \cdot 779$ & 33.779 & 0.312 & NS & \\
\hline $\begin{array}{l}\text { Breeding } \times \text { father } \\
\text { interaction }\end{array}$ & 14 & $1498 \cdot 526$ & 107.038 & $1 \cdot 231$ & NS & $7.5 \%$ \\
\hline $\begin{array}{l}\text { Breeding } \times \text { paternal } \\
\text { type interaction }\end{array}$ & 1 & $36 \cdot 130$ & $36 \cdot 130$ & 0.415 & NS & \\
\hline Maternal $F_{1}$ type & 1 & $36 \cdot 130$ & $36 \cdot 130$ & 0.337 & NS & \\
\hline $\begin{array}{l}\text { Maternal type } \times \\
\text { paternal type } \\
\text { interaction }\end{array}$ & 1 & $33 \cdot 779$ & 33.779 & 0.389 & NS & \\
\hline $\begin{array}{l}\text { Maternal type } \times \text { father } \\
\text { interaction }\end{array}$ & 14 & $1498 \cdot 526$ & $107 \cdot 038$ & $1 \cdot 231$ & NS & \\
\hline Total treatments & 31 & $7275 \cdot 172$ & 234.683 & $2 \cdot 700$ & 0.005 & $36.4 \%$ \\
\hline Residual & 146 & $12,690 \cdot 833$ & 86.923 & & & \\
\hline Total & 177 & $19,966 \cdot 006$ & & & & \\
\hline
\end{tabular}

3c. Total number of courtship displays (CO)

\begin{tabular}{|c|c|c|c|c|c|c|}
\hline Source & $\mathrm{df}$ & $\begin{array}{l}\text { Sum of } \\
\text { squares }\end{array}$ & $\begin{array}{l}\text { Mean } \\
\text { square }\end{array}$ & $F$ ratio & Significance & $C D$ \\
\hline Paternal $F_{1}$ type & 1 & $156 \cdot 295$ & $156 \cdot 295$ & 0.485 & NS & \\
\hline Father $1 F_{1}$ type & 14 & $4512 \cdot 906$ & $322 \cdot 350$ & $4 \cdot 334$ & 0.005 & $25.6 \%$ \\
\hline Breeding & 1 & 0.048 & 0.048 & $0 \cdot 001$ & NS & \\
\hline $\begin{array}{l}\text { Breeding } \times \text { father } \\
\text { interaction }\end{array}$ & 14 & $1834 \cdot 615$ & $131 \cdot 044$ & $1 \cdot 762$ & 0.05 & $10 \cdot 4 \%$ \\
\hline $\begin{array}{l}\text { Breeding } \times \text { paternal } \\
\text { type interaction }\end{array}$ & 1 & 27.769 & $27 \cdot 769$ & 0.373 & NS & \\
\hline Maternal $F_{1}$ type & 1 & $27 \cdot 769$ & $27 \cdot 769$ & 0.212 & NS & \\
\hline $\begin{array}{l}\text { Maternal type } \times \\
\text { paternal type } \\
\text { interaction }\end{array}$ & 1 & 0.048 & 0.048 & 0.001 & NS & \\
\hline $\begin{array}{l}\text { Maternal type } \times \text { father } \\
\text { interaction }\end{array}$ & 14 & $1834 \cdot 615$ & $131 \cdot 044$ & 1.762 & 0.05 & \\
\hline Total treatments & 31 & $6781 \cdot 726$ & $218 \cdot 765$ & $2 \cdot 941$ & 0.005 & $38.4 \%$ \\
\hline Residual & 146 & $10,859 \cdot 133$ & $74 \cdot 378$ & & & \\
\hline Total & 177 & $17,640 \cdot 860$ & & & & \\
\hline
\end{tabular}

were highly significant half-sib effects (common father) on every trait, as well as father $\times$ breeding system interactions for all but the number of open courtship displays and the proportion of all displays that were of the open type. One variable, the number of closed courtship displays, showed a significant paternal $\mathrm{F}_{1}$ type $\times$ breeding interaction.

To re-use sums of squares from the above analysis for tests of the effects of maternal $F_{1}$ type on sexual behaviour of males, it was necessary to recalculate two $\mathrm{F}$ ratios because of the nature of the mixed model design (table 1). Maternal $F_{1}$ type had no detectable effect on any trait measured (despite the significant paternal $F_{1}$ type $\times$ breeding interaction for number 
3d. Proportion of total number of courtship displays of the open type $(\mathrm{O} / \mathrm{CO})$

\begin{tabular}{|c|c|c|c|c|c|c|}
\hline Source & df & $\begin{array}{l}\text { Sum of } \\
\text { squares }\end{array}$ & $\begin{array}{l}\text { Mean } \\
\text { square }\end{array}$ & F ratio & Significance & $\mathrm{CD}$ \\
\hline Paternal $F_{1}$ type & 1 & $0 \cdot 102$ & $0 \cdot 102$ & $0 \cdot 207$ & NS & \\
\hline Father $1 F_{1}$ type & 14 & 6.894 & 0.493 & $5 \cdot 109$ & 0.005 & $29 \cdot 2 \%$ \\
\hline Breeding & 1 & $0 \cdot 123$ & $0 \cdot 123$ & 0.830 & NS & \\
\hline $\begin{array}{l}\text { Breeding } \times \text { father } \\
\text { interaction }\end{array}$ & 14 & $2 \cdot 068$ & $0 \cdot 148$ & $1 \cdot 532$ & NS & $8 \cdot 7 \%$ \\
\hline $\begin{array}{c}\text { Breeding } \times \text { paternal } \\
\text { type interaction }\end{array}$ & 1 & $0 \cdot 170$ & $0 \cdot 170$ & $1 \cdot 765$ & NS & \\
\hline Maternal $F_{1}$ type & 1 & $0 \cdot 170$ & $0 \cdot 170$ & $1 \cdot 152$ & NS & \\
\hline $\begin{array}{l}\text { Maternal type } \times \\
\text { paternal type } \\
\text { interaction }\end{array}$ & 1 & $0 \cdot 123$ & $0 \cdot 123$ & $1 \cdot 272$ & NS & \\
\hline $\begin{array}{l}\text { Maternal type } \times \text { father } \\
\text { interaction }\end{array}$ & 14 & $2 \cdot 068$ & $0 \cdot 148$ & $1 \cdot 532$ & NS & \\
\hline Total treatments & 31 & 9.571 & 0.309 & $3 \cdot 202$ & 0.005 & $40.5 \%$ \\
\hline Residual & 146 & 14.073 & 0.096 & & & \\
\hline Total & 177 & $23 \cdot 643$ & & & & \\
\hline
\end{tabular}

3e. Gonopodial thrusts $(T)$

\begin{tabular}{|c|c|c|c|c|c|c|}
\hline Source & df & $\begin{array}{l}\text { Sum of } \\
\text { squares }\end{array}$ & $\begin{array}{l}\text { Mean } \\
\text { square }\end{array}$ & $\mathrm{F}$ ratio & Significance & CD \\
\hline Paternal $F_{1}$ type & 1 & 0.779 & 0.779 & $0 \cdot 115$ & NS & \\
\hline Father $1 F_{1}$ type & 14 & 94.679 & 6.793 & $18 \cdot 749$ & 0.005 & $56.0 \%$ \\
\hline Breeding & 1 & $0 \cdot 166$ & $0 \cdot 166$ & $0 \cdot 155$ & NS & \\
\hline $\begin{array}{l}\text { Breeding } \times \text { father } \\
\text { interaction }\end{array}$ & 14 & 14.973 & 1.069 & $2 \cdot 965$ & 0.005 & $8.9 \%$ \\
\hline $\begin{array}{l}\text { Breeding } \times \text { paternal } \\
\text { type interaction }\end{array}$ & 1 & $0 \cdot 123$ & 0.123 & 0.342 & NS & \\
\hline Maternal $F_{1}$ type & 1 & $0 \cdot 123$ & $0 \cdot 123$ & 0.115 & NS & \\
\hline $\begin{array}{l}\text { Maternal type } \times \\
\text { paternal type } \\
\text { interaction }\end{array}$ & 1 & $0 \cdot 166$ & $0 \cdot 166$ & 0.460 & NS & \\
\hline $\begin{array}{l}\text { Maternal type } \times \text { father } \\
\text { interaction }\end{array}$ & 14 & 14.973 & $1 \cdot 069$ & $2 \cdot 965$ & 0.005 & \\
\hline $\begin{array}{l}\text { Total treatments } \\
\text { Residual }\end{array}$ & $\begin{array}{r}31 \\
146\end{array}$ & $\begin{array}{r}116 \cdot 472 \\
52 \cdot 657\end{array}$ & $\begin{array}{l}3 \cdot 757 \\
0 \cdot 361\end{array}$ & $10 \cdot 416$ & 0.005 & $68.9 \%$ \\
\hline Total & 177 & $169 \cdot 130$ & & & & \\
\hline
\end{tabular}

of closed courtship displays), and there were no maternal $F_{1}$ type $\times$ paternal $F_{1}$ type interactions. The $F$ ratios for individual father $\times$ maternal $F_{1}$ type interactions were identical to those for breeding $\times$ father interactions, so all but those for $\mathrm{O}$ and $\mathrm{O} / \mathrm{CO}$ were significant.

The significant effects of having a common father and the significant breeding $\times$ father interactions are clearly seen for two traits, total number of courtship displays and number of gonopodial thrusts, in fig. 2. The other four traits were similar. Every trait displays a complex set of interactions that, in net effect, cancel one another, rendering impossible the detection of an additive effect of the breeding system. Although the statistical design 
3f. Ratio of number of gonopodial thrusts to number of courtship displays (T/CO)

\begin{tabular}{|c|c|c|c|c|c|c|}
\hline Source & df & $\begin{array}{l}\text { Sum of } \\
\text { squares }\end{array}$ & $\begin{array}{l}\text { Mean } \\
\text { square }\end{array}$ & $F$ ratio & Significance & $\mathrm{CD}$ \\
\hline Paternal $F_{1}$ type & 1 & $0 \cdot 112$ & $0 \cdot 112$ & 0.003 & NS & \\
\hline Father $1 \mathrm{~F}_{1}$ type & 14 & $58 \cdot 131$ & $4 \cdot 152$ & $10 \cdot 469$ & 0.005 & $42 \cdot 8 \%$ \\
\hline Breeding & 1 & 0.093 & 0.093 & 0.084 & NS & \\
\hline $\begin{array}{l}\text { Breeding } \times \text { father } \\
\text { interaction }\end{array}$ & 14 & $15 \cdot 560$ & $1 \cdot 111$ & $2 \cdot 802$ & 0.005 & $11 \cdot 5 \%$ \\
\hline $\begin{array}{l}\text { Breeding } \times \text { paternal } \\
\text { type interaction }\end{array}$ & 1 & $0 \cdot 303$ & $0 \cdot 303$ & $0 \cdot 765$ & NS & \\
\hline Maternal $F_{1}$ type & 1 & $0 \cdot 303$ & $0 \cdot 303$ & $0 \cdot 273$ & NS & \\
\hline $\begin{array}{l}\text { Maternal type } \times \\
\text { paternal type } \\
\text { interaction }\end{array}$ & 1 & 0.093 & 0.093 & 0.235 & NS & \\
\hline $\begin{array}{l}\text { Maternal type } \times \text { father } \\
\text { interaction }\end{array}$ & 14 & $15 \cdot 560$ & $1 \cdot 111$ & $2 \cdot 802$ & 0.005 & \\
\hline Total treatments & 31 & $77 \cdot 818$ & $2 \cdot 510$ & $6 \cdot 329$ & 0.005 & $57 \cdot 3 \%$ \\
\hline Residual & 146 & $57 \cdot 901$ & $0 \cdot 397$ & & & \\
\hline Total & 177 & $135 \cdot 719$ & & & & \\
\hline
\end{tabular}

does not allow for a direct test of $Y$-linkage of sexual behavioural measures, that the coefficients of determination for the effects of having a common father (table 3) are 2-6 times higher than those for presumed autosomal contributions from mothers (see below) suggests that the paternal contribution includes $Y$-linked as well as autosomal genes.

What is the biological significance of the father $\times$ breeding system interactions? Interactions are not merely a reflection of different magnitudes of a generally unidirectional phenomenon (fig. 2). Rather, whatever caused the interaction determined whether the lines went up or down. If we remove the labels "outbred" and "inbred" or "HT mother" and "TH mother", we are left with the fact that one male was paired with each of two different females. The differences between crosses within fathers can thus be attributed to $X$-linked factors, general autosomal effects, or non-genetic maternal effects.

Farr (1983) found no evidence for $X$-linked genes affecting male behaviour and very small non-genetic maternal effects. Autosomal factors are thus most likely causing the significant interactions. In table 4 we compare the magnitude of supposed autosomal effects on male sexual behaviour from three independent sets of crosses. The first two are from Farr (1983), one in which two inbred strains, their $F_{1}$ hybrids, and four backcrosses were observed, and the second from crosses between normal $\mathrm{XY}$ males and sex-reversed XY females. The third is from the present study and used fish unrelated to those in the first two data sets. Furthermore, one of us (JAF) performed all quantitative observations for the first set, while the other (KP) performed all those for the second and third data sets. The magnitude of the autosomal effects is expressed as coefficients of determination, the percentage of the total variance accounted for by autosomal factors.

There is surprising agreement among the three data sets in the contribution of autosomal factors to quantitative male sexual behaviour patterns. Generally, approximately ten percent of the total variance can be accounted 

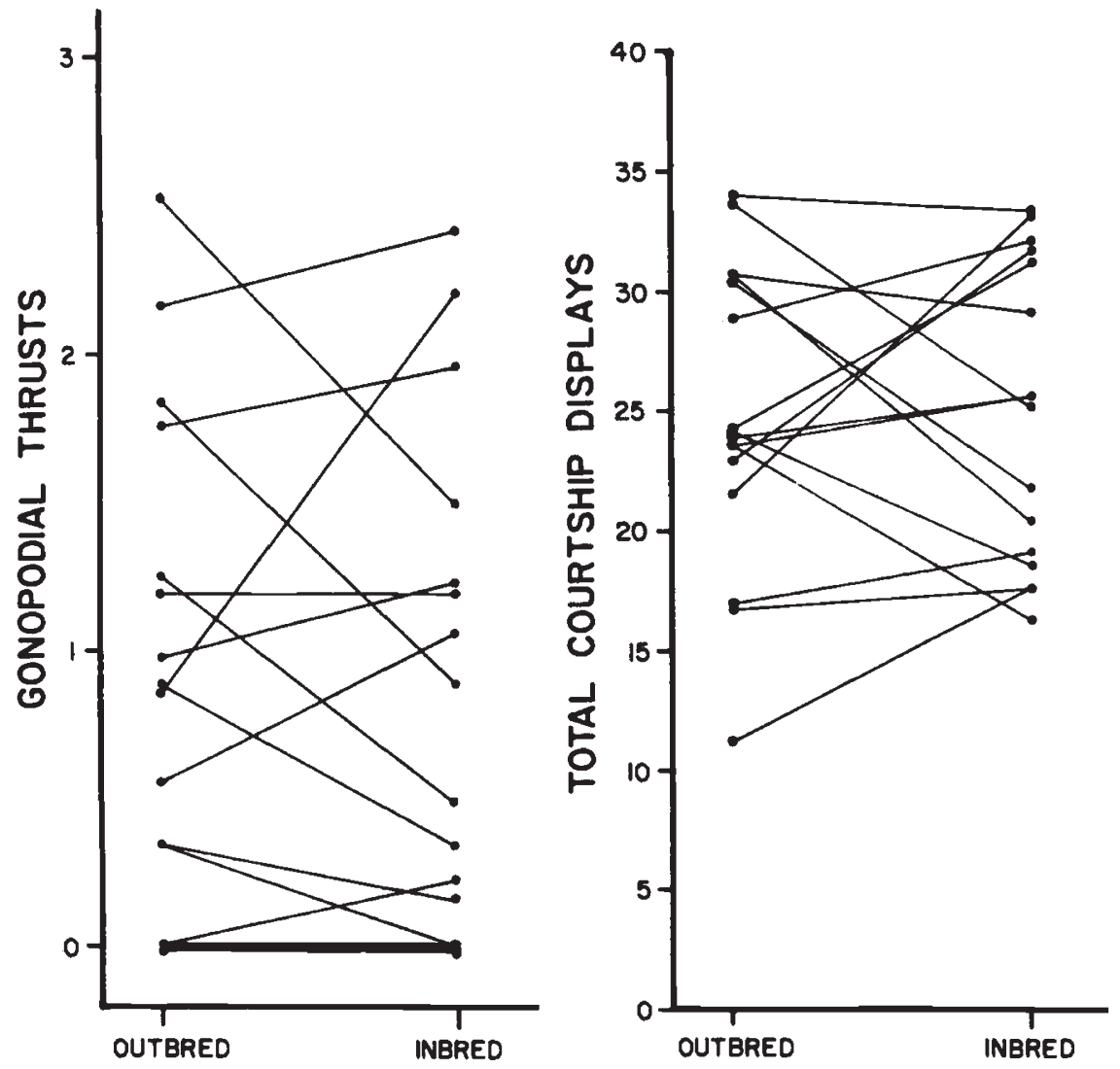

FIG. 2. Representations of half-sib (common father) effects and father $\times$ breeding system interactions on two of six male sexual behaviour patterns. Each line represents one father, each point a full-sib family. Variation within full-sib families is not depicted. The graph for Gonopodial Thrusts is with transformed data.

TABLE 4

Coefficients of determination for autosomal effects on male sexual behaviour from three different sets of crosses

\begin{tabular}{cccc}
\hline & $\begin{array}{c}\text { Crosses with } \\
\text { two strains }\end{array}$ & $\begin{array}{c}\text { Crosses with } \\
\text { XY females }\end{array}$ & $\begin{array}{c}\text { Inbreeding } \\
\text { crosses }\end{array}$ \\
\hline $\mathrm{C}$ & 9.2 & 12.1 & $10 \cdot 2$ \\
$\mathrm{O}$ & 6.2 & 9.6 & 7.5 \\
$\mathrm{CO}$ & 12.1 & 10.7 & 10.4 \\
$\mathrm{~T}$ & 17.3 & 8.1 & 8.9 \\
\hline
\end{tabular}

for by autosomal factors, with number of open courtship displays showing consistently less autosomal influence than either closed displays or total number of displays. If an extreme value is to be found, the autosomal contribution to rate of gonopodial thrusting in the first data set (17.3 per cent) is much higher than the rest. 
We conclude from these analyses that one generation of full-sib inbreeding does not result generally in significantly reduced male sexual activity in the populations, although this effect can occur in the progeny of some males. Farr (1983) found a significant positive relationship between level of heterozygosity and male sexual activity. The results do corroborate other aspects of Farr's earlier work, although indirectly. No direct test of $Y$ linkage of sexual behaviour patterns was possible, but the highly significant effects of having a common father support $Y$-linkage. Furthermore, general autosomal influences on the primarily $Y$-linked traits are consistent over three data sets.

\section{Discussion}

There were no detectable overall effects of one generation of inbreeding on any quantitative male sexual behaviour patterns examined despite the apparent general positive correlation between level of heterozygosity and some aspects of male sexual behaviour reported earlier (Farr, 1983). The highly significant interactions between breeding system and individual fathers indicate that breeding system can affect different genotypes differently, however, so it is incorrect to conclude that breeding system has no effect on male sexual behaviour whatsoever.

Because Farr (1983) used highly inbred strains in his previous study, it is possible that the $F_{1}$ generations were much more heterozygous than the TH and HT individuals used here, and that the difference in number of heterozygous loci between Farr's (1983) $F_{1}$ and backcross generations was much greater than the difference between our present inbred and outbred individuals. Consequently, further generations of inbreeding might have resulted in the overall depression of behaviour reported earlier. However, the tendency of female guppies to mate with rare or novel males (Farr, $1977,1980 a$ ) would probably prevent more than a single generation of inbreeding in natural populations.

A second consideration concerning the lack of inbreeding effects on male behaviour is that inbreeding might have resulted in reduced male sexual behaviour if the fish had not been reared under constant conditions. If heterozygosity provides a buffer against a fluctuating environment (Lewontin, 1956, 1958; Bryant, 1974; Johnson, 1974, 1976; Wool and Sverdlov, 1976; Templeton and Rothman, 1978a, 1978b; MacKay, 1981), perhaps developmental abnormalities under fluctuating laboratory conditions would have been manifested as a reduction in sexual activity in the inbred offspring. At present we can only speculate.

Despite the lack of an overall additive effect of breeding system on sexual behaviour, we cannot conclude that inbreeding is not deleterious in guppies. Beardmore and Shami (1979) demonstrated that individuals exhibiting low heterozygosity at various isozyme loci had shorter lifespans, exhibited the most extreme numbers of caudal fin rays (an indication of reduced homeostatic abilities), and were less fecund. These effects would not have as immediate an effect as reduced male sexual behaviour, but they are nonetheless harmful in the long run.

Our data are consistent with the major patterns of inheritance reported by Farr (1983). Farr's previous work used several inbred laboratory strains, and because the fish used in our present study were derived recently from 
wild populations, it is probable that $\mathrm{Y}$-linkage of male behavioural traits in guppies is a general phenomenon and not peculiar to a few laboratory strains. Autosomal factors act primarily as a mechanism for fine-tuning, but their mode of action is obviously very complex.

That the three independent data sets show similar autosomal contributions to quantitative male behaviour patterns does not imply similar modes of action. Farr predicted previously that autosomal and, perhaps, X-linked influences on male behaviour might be stronger in some populations than in others, and the different data sets might reflect qualitative variation in the fine-tuning mechanisms. The present study makes clear that detailed genetic analyses of natural populations are essential. Further studies on inbreeding are also necessary, particularly in view of female preferences for rare or novel males (Farr, 1977, 1980a), a possible behavioural response maximising outbreeding and heterozygosity in a temporally fluctuating environment (Lacy, 1979; Farr, 1980a).

Acknowledgments. We wish to thank L. Kern and A. Sedlmeier for maintaining and rearing the fish. J. Favor and J. Travis were instrumental in both the design of the experiment and the subsequent data analysis. The critical comments of J. Travis resulted in a greatly improved final manuscript. Computer time for data analysis was supplied by the Department of Biological Science, Florida State University. This work was supported by a grant from the Deutsche Forschungsgemeinschaft to Prof J. H. Schröder.

\section{REFERENCES}

BAERENDS, G. P., BROUWER, R. AND WATERBOLK, H. TJ. 1955. Ethological studies on Lebistes reticulatus (Peters). I. An analysis of the male courtship pattern, Behaviour, 8, 249-335.

BEARDMORE, J. A. AND SHAMI, S. A. 1979. Heterozygosity and the optimum phenotype under stabilising selection. Aquilo Ser. Zool., 20, 100-110.

BRÜCKNER, D. 1975. Die Abhängigkeit der Temperaturregulierung von der genetischen Variabilität der Honigbiene (Apis mellifera). Apidologie, 6, 361-380.

BRÜCKNER, D. 1976. Vergleichende Untersuchungen zur Temperatur-praeferenz von ingezüchteten und nicht-ingezüchteten Arbeiterinnen der Honigbiene (Apis mellifera). Apidologie, 7, 139-149.

BRÜCKNER, D. 1978. Why are there inbreeding effects in haplo-diploid systems? Evolution, 32, 456-458.

BRYANT, E. H. 1974. On the adaptive significance of enzyme polymorphisms in relation to environmental variability. Amer. Natur., 108, 1-19.

CROW, J. F. AND KIMURA, M. 1970. An Introduction to Population Genetics Theory. Harper and Row, New York.

FAlCONER, D. S. 1960. Introduction to Quantitative Genetics. Ronald Press, New York.

FARR, J. A. 1976. Social facilitation of male sexual behavior, intrasexual competition, and sexual selection in the guppy, Poecilia reticulata (Pisces: Poeciliidae). Evolution, 30 , 707-717.

FARR, J. A. 1977. Male rarity or novelty, female choice behavior, and sexual selection in the guppy, Poecilia reticulata Peters (Pisces: Poeciliidae). Evolution, 31, 162-168.

FARR, J. A. $1980 a$. Social behavior patterns as determinants of reproductive success in the guppy, Poecilia reticulata Peters (Pisces: Poeciliidae) -an experimental study of the effects of intermale competition, female choice, and sexual selection. Behaviour, 74, 38-91.

FARR, J. A. $1980 \mathrm{~b}$. The effects of sexual experience and female receptivity on courtship-rape decisions in male guppies, Poecilia reticulata (Pisces: Poeciliidae). Anim. Behav., 28, 1195-1201.

FARR, J. A. 1983. The inheritance of quantitative fitness traits in guppies, Poecilia reticulata (Pisces: Poeciliidae). Evolution, 37, 1193-1209.

FARR, J. A. AND HERRNKIND, W, F. 1974. A quantitative analysis of social interaction of the guppy, Poecilia reticulata (Pisces: Poeciliidae), as a function of population density. Anim. Behav., 22, 582-591. 
FULKER, D, W, 1966. Mating speed in male Drosophila melanogaster: a psychogenetic analysis. Science, 153, 203-205.

HAYS, W. L. 1973. Statistics for the Social Sciences. Holt, Rinehart, and Winston, New York. HILDEMANN, W. H. AND WAGNER, E. D. 1954. Intraspecific sperm competition in Lebistes. Amer. Natur., 88, 87-91.

JAKWAY, J. S. 1959. Inheritance of patterns of mating behaviour in the male guinea pig. Anim. Behav., 7, 150-162.

JOHNSON, G. B. 1974. Enzyme polymorphism and metabolism. Science, 184, 28-37.

JOHNSON, G. B. 1976. Genetic polymorphism and enzyme polymorphism. In Ayala, F. J. (ed.) Molecular Evolution. Sinauer Associates, Inc., Sunderland, Mass., pp. 46-59.

KADOW, P. 1954. An analysis of sexual behavior and reproductive physiology in the guppy, Lebistes reticulatus (Peters). Ph.D. Thesis, New York Univ.

LACY, R. C. 1979. Adaptiveness of a rare male mating advantage under heterosis. Behav. Genet., 9, 51-54.

LEWONTIN, R. C. 1956. Studies on homeostasis and heterozygosity I. General considerations. Abdominal bristle number in second chromosome homozygotes of Drosophila melanogaster. Amer. Natur., 90, 237-255.

LEWONTIN, R. C. 1958. Studies on homeostasis and heterozygosity II. Loss of heterosis in a constant environment. Evolution, 12, 494-503.

LILEY, N. R. 1966. Ethological isolating mechanisms in four sysmpatric species of poeciliid fishes. Behaviour, Suppl. 13, 1-197.

MACKAY, T. F. C. 1981. Genetic variation in varying environments. Genet. Res., Camb., 37, 79-93.

MAYNARD-SMITH, J. 1956. Fertility, mating behaviour and sexual selection in Drosophila subobscura. J. Genet., 54, 261-279.

MCGILL, T. E. 1970. Genetic analysis of male sexual behavior. In Lindzey, G. and Thiessen, D. D. (eds.) Contributions to Behaviour-Genetic Analysis: The Mouse as a Prototype Appleton, New York, pp. 57-88.

PACKER, C. 1979. Inter-troop transfer and inbreeding avoidance in Papio anubis. Anim. Behav., 27, 1-36.

RALLS, K., BRUGGER, K. AND BALLOU, J. 1979. Inbreeding and juvenile mortality in small populations of ungulates. Science, 206, 1101-1103.

TEMPLETON, A. R. AND ROTHMAN, E. D. 1978a. Evolution and fine-grained environmental runs. In Hooker, C., Leach, J. J. and McClennan, E. F. (eds.) Foundations and Applications of Decision Theory, Vol. II Reidel, Boston, pp. 131-183.

TEMPLETON, A. R. AND ROTHMAN, E. D. 1978b. Evolution in fine-grained environments 1. Environmental runs and the evolution of homeostasis. Theoret. Pop. Biol., 13, 340-355. WINGE, O. 1937. Succession of broods in Lebistes. Nature, 140, 467.

WOOL, D. AND SVERDLOV, E. 1976. Sib-mating populations in an unpredictable environment: effects on components of fitness. Evolution, 30, 119-129.

WRIGHT, S. 1977. Evolution and the Genetics of Populations, Vol. 3, Experimental Results and Evolutionary Deductions. Univ. Chicago Press, Chicago. 